\title{
Upaya Antisipatif Menghadapi Covid-19 Di Era Disruptif Melalui Pengembangan Antologi Puisi Berbasis Ecopreneurship
}

\author{
Sani Aryanto ${ }^{1,}$, , Nunuy Nurkaeti ${ }^{1}$, Asep Nuryadin ${ }^{2}$ \\ ${ }^{1}$ Fakultas IImu Pendidikan; Universitas Bhayangkara Jakarta Raya; Jl. Raya \\ Perjuangan, Marga Mulya, Bekasi Utara, Jawa Barat 17121. Telp: 021-88955882, 889955883; \\ e-mail: sani.aryanto@dsn.ubharajaya.ac.id; nunuy.nurkaeti@dsn.ubharajaya.ac.id; \\ ${ }^{2}$ Faculty of Education; Monash University; Wellington Rd, Clayton VIC 3800, Australia; \\ email: anur0004@student.monash.edu \\ * Korespondensi: e-mail: sani.aryanto@dsn.ubharajaya.ac.id
}

\begin{abstract}
Ecopreneurship is regarded as a concept to accommodate Indonesia's problems in the economic, environment, and education in the disruptive era during Covid-19 pandemic, the perspective of the educationness, the research aims to develop an anthology of poetry-based ecopreneurship to be an anticipatory effort in to solve the problems. The research method uses the design of Research and Development (R\&D), Hope fully this method can explain the theoretical basic to develop anthology of ecopreneurship and to give an overview of the process of developing a poetry-based ecopreneurship concept. The results of this research are two phases of four phases to do, so that the presented data includes relevant theories to develop poetry anthology such as: The concept of ecopreneurship, the values of ecopreneurship, the characteristics of children's poetry, and the internalization ecopreneurship values on children's poetry. The development stage of anthology has reached 50\% with the number of poetry reached 40 is expected to actually represent the concept of ecopreneurship in elementary school
\end{abstract}

Keywords: Ecopreneurship, Poetry, Covid-19

\begin{abstract}
Abstrak
Ecopreneurship dianggap sebagai konsep yang diharapkan mampu mengakomodir permasalahan Bangsa Indonesia di bidang ekonomi, lingkungan, dan pendidikan di era disruptif selama masa pandemi Covid-19 dari prespektif bidang kependidikandasaran, sehingga penelitian ini bertujuan untuk mengembangkan antologi puisi berbasis ecopreneurship yang diharapkan mampu menjadi upaya antisipatif dalam menyikapi permasalahan yang terjadi saat ini. Metode penelitian menggunakan desain research and development $(R \& D)$ dengan harapan mampu menjelaskan landasan teoretis dalam pengembangan antologi berbasis ecopreneurship dan mampu memberikan gambaran proses pengembangan rancangan awal antologi puisi berbasis ecopreneurship. Hasil penelitian ini merupakan dua tahapan dari empat tahapan yang telah dan akan dilakukan sehingga data-data yang disajikan meliputi teori-teori yang relevan dengan pengembangan antologi puisi seperti: konsep ecopreneurship, nilai-nilai ecopreneurship, karakteristik puisi anak, dan internalisasi nilai-nilai ecopreneurship pada puisi anak. Tahap pengembangan antologi sudah mencapai $50 \%$ dengan jumlah puisi mencapai 40 karya yang diharapkan benar-benar merepresentasikan konsep ecopreneurship di sekolah dasar.
\end{abstract}

Kata kunci: Ecopreneurship, Puisi, Covid-19 


\section{Pendahuluan}

Pandemi Covid-19 yang terjadi saat ini berimpliksi terhadap tatanan kehidupan yang tidak berjalan normal seperti biasanya. Kini terjadi lonjakan yang sangat signifikan dengan jumlah korban yang terpapar semakin bertambah dengan angka mortalitas yang menunjukan fluktuasi maksimum.(Singh \& Subedi, 2020). Virus yang disinyalir berasal dari Wuhan dan tercatat mulai merebak di akhir tahun 2019 memberikan dampak terhadap modifikasi kebijakan dalam beberapa bidang, hal ini mengakibatkan perubahan pola interkasi dalam kehidupan sehari-hari. (Fan et al., 2020; Sanchis-Gomar et al., 2020). Berbagai upaya telah dilakukan dan salah satu upaya kuratif yang mulai diimplementasikan adalah penerapan era "New Normal" untuk mengantisipasi permasalahan-permasalahan yang kerap terjadi selama masa Covid-19 terutama di bidang ekonomi, sosial, lingkungan, dan Pendidikan (Bikdeli et al., 2020).Covid-19 menjadi bahan refleksi negeri ini karena musibah yang terjadi tidak lepas dari pola perilaku penduduk Indonesia yang tidak ramah terhadap lingkungan. Walaupun Indonesia diyakini memiliki potensi demografi yang sangat baik dan diperkirakan mengalami masa keemasan di Tahun 2045 (Aryanto, 2016) nyatanya dengan adanya musibah Covid-19 seolah menjadi indikator bahwa Indonesia harus terus berbenah dan mencari upaya solutif secara preventif maupun kuratif dalam menghadapi permasalahan-permasalahan yang terjadi hingga saat ini (Kiky, 2020).

Hasil Global Competitive Index menunjukan bahwa Indonesia berada diperingkat 38 dari 139 negara. Pencapaian itu tidak cukup baik apabila melihat demografi Bangsa Indonesia yang sangat besar secara kuantitas. Namun secara kualitas, Bangsa Indonesia memiliki permasalahan dalam tiga aspek, diantaranya: Pertama permasalahan ekonomi yang disebabkan perilaku produktif lebih sedikit dibandingkan dengan perilaku konsumtif, Kedua permasalahan lingkungan alam yang berimplikasi terhadap buruknya sistem kesehatan. Ketiga, permasalahan pendidikan terutama di bidang kependidikandasaran yang masih bersifat segregasi dan minimnya penyelenggaraan pendidikan inklusif. (Aryanto et al., 2019; Aryanto \& Widiansyah, 2019) Ketiga permasalahan tersebut merupakan prioritas yang harus dituntaskan di tengah musibah Covid-19 yang terjadi hingga kini.

Dalam mengatasi wabah COVID-19, pemerintah tidak melakukan karantina wilayah (lock down) tetapi menggunakan kebijakan Pembatasan Sosial Berskala Besar (PSBB). Dimulai dari ibukota Jakarta, kebijakan ini diikuti oleh wilayah lainnya. Kota Bekasi sebagai wilayah penyangga Jakarta segera menerapkan kebijakan PSBB mengingat wilayah ini berdekatan dengan dikhawatirkan terpengaruh dengan kota Jakarta yang merupakan zona merah dengan hampir separuh kasus COVID-19 ada di wilayah Jakarta. Banyak pihak yang mendukung dan juga kurang setuju dengan PSBB, namun agar perekonomian tetap berjalan dan wabah dapat diatasi, pemerintah tidak mengambil kebijakan karantina wilayah. Untuk mengetahui efektifitas PSBB di kota Bekasi, penelitian ini mencoba menggunakan model Susceptible-Infected Recoverd (SIR) untuk mengukur laju penyebaran COVID-19. Hasilnya menunjukan adanya laju 
penurunan kasus terinfeksi dengan beta dan gamma beruturut-turut sebesar 0,071 dan 0,05 dan diprediksi akan berakhir di bulan Juni 2020. (Handayanto \& Herlawati, 2020).

Hal tersebut didukung oleh beberapa riset di seluruh dunia dalam memprediksi puncak sebaran COVID-19 yang beberapa negara sudah masuk dalam masa lonjakan kedua. Untuk wilayah Indonesia beberapa peneliti menggunakan pendekatan soft computing, seperti Support Vector Machine (SVM) regression, dengan beberapa kernel pilihan, antara lain radial basis function, linear and polynomial dengan akurasi yang beragam. Alat bantu dari Google (Google Interactive Notebook) sangat membantu dengan fasilitas kompiler dan servernya (Herlawati, 2020).

Ecopreneurship dipandang sebagai solusi yang dapat mengakomodasi ketiga permasalahan utama yang dihadapkan Bangsa Indonesia saat ini. Secara konseptual, ecopreneurship merupakan bentuk pengintegrasian antara konsep ecolitercy dan entrepreneurship. Konsep ini pertama kali dikembangkan oleh Schaper yang mendefinisikan ecopreneurship sebagai bentuk wirausaha yang berwawasan lingkungan dalam menjalankan usahanya (Schaper, 2002). Pada mulanya konsep ini diimplementasikan di dunia ekonomi dan belum secara masif diinternalisasikan dalam berbagai bidang, termasuk bidang pendidikan. Setiap guru SD harus mampu menginisiasi upaya internalisasi nilai-nilai ecopreneurship dalam seluruh interverensi pembelajaran secara kreatif. Salah satu pembelajaran yang dapat dipilih dalam menginternalisasikan nilai-nilai dan karakter pada diri siswa adalah pembelajaran puisi. Puisi diyakini sebagai sebagai cara tepat dalam internalisasi nilai-nilai kemanusiaan dan berkaitan dengan hakikat pendidikan dalam upaya memanusiakan manusia (Aryanto \& Widiansyah, 2019). Melalui puisi, anak akan menghayati kejadian-kejadian di lingkungan sekitarnya.

Puisi menyediakan pengalaman hidup artinya pengalaman anak digali melalui pengalamannya ketika membaca puisi. Selain itu, teks sastra mengajarkan karakter tanpa harus menggurui (Aryanto, Rony, et al., 2020). Namun sayangnya penelitian dan ketersediaan bahan bacaan sastra anak di SD tergolong masih terbatas apalagi puisi yang mengandung nilai-nilai ecopreneurship. Oleh karena itu hasil penelitian ini diharapkan mampu menjabarkan landasan teoretis dari penyusunan dan pengembangan antologi sastra anak berbasis ecopreneurship (2) Merancang desain antologi sastra anak berbasis ecopreneurship.

Hasil penelitian ini diharapkan mampu menjadi referensi guru dalam mengembangkan inovasi pembelajaran sastra anak yang secara implisit dapat dijadikan upaya antisipatif dalam menghadapi era disrupsi selama pandemi covid-19.

\section{Metode Penelitian}

Penelitian ini menggunakan desain research and development $(R \& D)$ dengan model yang merujuk pada pendapat Borg dan Gall (1989) yang disesuaikan dengan bidang pendidikan. Berikut tahapan utama dalam penelitian ini terdapat dalam gambar 1. 


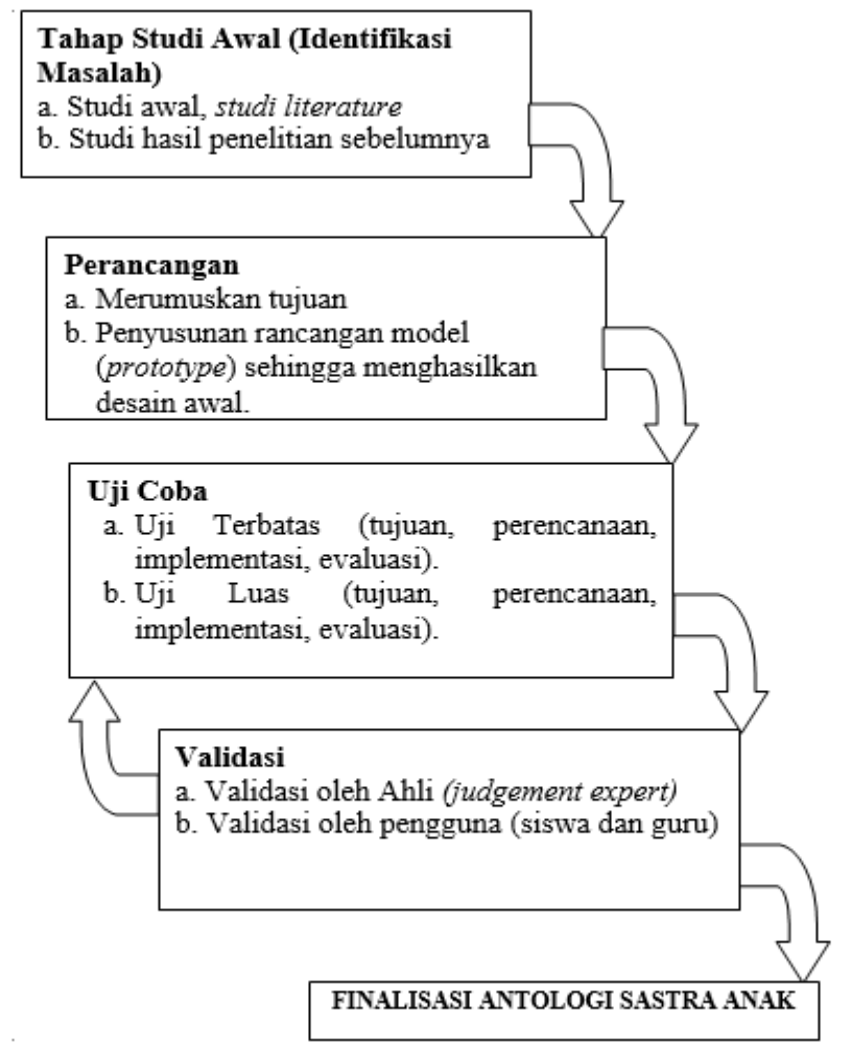

Gambar 1. Bagan Desain Penelitian Pengembangan Antologi Puisi Anak berbasis Ecopreneurship

Berdasarkan gambar 1 dapat diketahui bahwa terdapat beberapa tahapan penelitian yang dilakukan selama proses penelitian. Adapun hasil penelitian ini merupakan tahap pertama dan kedua dalam penelitian pengembangan antologi puisi anak berbasis ecopreneurship sehingga gambaran hasil penelitian ini mencangkup dua permasalahan utama yaitu mengkaji landasan teoretis dalam pengembangan antologi puisi berbasis ecopreneurship dan gambaran rancangan pertama antologi puisi yang telah disusun. Berikut teknis analisis data penelitian ini diantaranya: (1) pengumpulan data yang relevan sesuai dengan variabel penelitian (2) peneliti menyajikan data-data yang telah terkumpul (3) reduksi dan inventarisasi data (4) menyimpulkan berdasarkan hasil verifikasi data yang valid dan reliabel (Cresswell dalam Aryanto and Widiansyah, 2019)

\section{Hasil dan Pembahasan}

\subsection{Ecopreneurship}

Ecopreneurship merupakan bentuk pengintegrasian antara konsep ecolitercy dan entrepreneurship. Konsep ecoliteracy merupakan pendekatan simbolis dan khusus terhadap lingkungan alam, sederhananya bahwa konsep ini menekankan pada manusia sebagai bagian makhluk hidup yang tidak lepas dari sistem ekologis sehingga secara alamiah sistem alam menjadi peletak dasar dalam berprilaku (Ekayanti et al., 2011; Nadiroh \& Siregar, 2019; Uslu et al., 2015) sedangkan konsep entrepreneurship merupakan sifat, ciri, dan watak seseorang yang memiliki kemauan dalam mewujudkan gagasan inovatif ke dalam dunia nyata sehingga kedua 
konsep menjadi landasan dalam membangun kerangka dasar konsep ecopreneurship secara definitif. Oleh karena itu dapat diartikan bahwa konsep ecopreneurship sebagai konsep yang mengarahkan manusia sebagai bagian dari sistem alam dan mampu menginternalisasikan nilainilai kewirausahaan sebagai landasan dalam berperilaku termasuk mempertimbangkan dampak dari perilaku wirausaha (Aryanto \& Syaodih, 2017; Dixon \& Clifford, 2007; Nacu \& Avasilcăi, 2014; Schaltegger, 2014). Hal ini sangat sesuai dengan kondisi Pandemi Covid-19 saat ini diamana terjadi ketimpangan antara pola prilaku manusia dan pemanfaatan lingkungan alam yang dianggap tidak dilakukan secara proporsional.

Konsep ini pertama kali dikembangkan oleh Schaper yang mendefinisikan ecopreneurship sebagai bentuk wirausaha yang berwawasan lingkungan dalam menjalankan usahanya (Schaper, 2002). Pada mulanya konsep ini diimplementasikan di dunia ekonomi dan belum secara masif diinternalisasikan dalam berbagai bidang, termasuk bidang pendidikan.Apabila merujuk pada prespektif bidang pendidikan, konsep ini memang tidak lepas dari konsep enterpreneurship dan ecoliteracy. Konsep ini pertama dikenalkan oleh Aryanto dalam penelitiannya yang berjudul : Development of Ecopreneurship in Primary School yang dipublikasikan dalam jurnal IJAEDU di Turki mendefinisikan ecopreneurship sebagai sebuah konsep yang diharapkan membuat peserta didik yang kreatif, inovatif dan semangat pantang menyerah seperti pengusaha yang diimbangi dengan perilaku ekologis, sehingga bisa menjaga, memanfaatkan, dan mengelola lingkungan alam dengan bijaksana (Aryanto \& Syaodih, 2017). Oleh karena itu, setiap guru SD harus mampu menginisiasi upaya internalisasi nilai-nilai ecopreneurship dalam seluruh interverensi pembelajaran secara kreatif dalam mengantisipasi dampak buruk era disruptif selama pandemi Covid-19. Salah satu pembelajaran yang dapat dipilih dalam menginternalisasikan nilai-nilai dan karakter pada diri siswa adalah pembelajaran puisi.

\subsection{Nilai-Nilai Ecoprenuership}

Era disruptif menginisiasi perubahan dalam berbagai bidang, termasuk bidang pendidikan (Rony \& Aryanto, 2020). Salah satu perubahan yang terjadi sebagai dampak dari era ini adalah digitalisasi sistem pendidikan yang mampu menggeser peranan guru oleh teknologi. Namun dua hal yang tidak dapat digantikan oleh teknologi adalah penanaman nilainilai dan karakter (Aryanto \& Widiansyah, 2019). Apalagi saat ini dunia sedang mengalami Pandemi Covid-19 yang mempengaruhi pola interaksi dilakukan tidak seperti biasanya (New Normal Era). Oleh karena itu perlu ada upaya antisipatif dalam menghadapi era disruptif selama pandemi covid-19. Salah satu upaya yang dapat dilakukan dalam dunia pendidikan adalah internalisasi nilai-nilai ecopreneurship dalam pembelajaran puisi di SD. Berikut nilai-nilai ecopreneurship sebagai referensi dalam pengembangan antologi puisi (Aryanto, Widiansyah, et al., 2020; Aryanto \& Widiansyah, 2019) diantaranya: (1) Mandiri; (2) kreatif; (3) berani mengambil resiko; (4) berorientasi pada tindakan; (5) kepemimpinan; (6) kerja keras; (7) jujur; (8) disiplin; (9) inovatif; (10) tanggung jawab; (11) kerjasama; (12) pantang menyerah; (13) 
komitmen; (14) realistis; (15) rasa ingin tahu; (16) komunikatif; (17) motivasi kuat; (18) Peduli terhadap lingkungan (Green Behaviour) meliputi: respect for the earth, care for life and adopt patterns of production, consumption, and reproduction. Indikatornya dapat dilihat dalam Tabel 1.

Tabel 1. Perilaku Berwawasan Lingkungan

\begin{tabular}{|c|c|c|}
\hline No & Key Principles & Green Behaviour \\
\hline 1. & Respect for the Earth & $\begin{array}{l}\text { a. Membuang sampah pada tempatnya } \\
\text { b. Memilah sampah organik dan anorganik } \\
\text { c. Menanam dan memelihara pohon di sekolah } \\
\text { d. Mematikan listrik pada ruang yang tidak dipakai }\end{array}$ \\
\hline 2. & Care for Life & $\begin{array}{l}\text { a. Memilih makanan organik } \\
\text { b. Memakai masker saat berpergian di jalan raya } \\
\text { c. Menegur teman yang melakukan tindakan tidak ramah lingkungan } \\
\text { d. Menghindari produk makanan yang mengandung pengawet }\end{array}$ \\
\hline 3. & $\begin{array}{l}\text { Adopt Patterns of } \\
\text { Production, Consumption, } \\
\text { and Reproduction }\end{array}$ & $\begin{array}{l}\text { a. Menghindari penggunaan kantung plastik } \\
\text { b. Mengkonsumsi barang yang ramah lingkungan } \\
\text { c. Menggunakan satu botol plastik yang bisa diisi ulang sebagai tempat } \\
\text { d. Minum }\end{array}$ \\
\hline
\end{tabular}

Sumber: (Aryanto et al., 2019)

Dalam pengembangannya puisi anak yang dibuat diharapkan mampu merepresentasikan 18 nilai-nilai ecoprenuership walaupun prioritas nilai yang diinternalisasikan dalam tahap pertama adalah nilai-nilai peduli terhadap lingkungan sebagai bentuk manifestasi solusi menghadapi era disrupsi selama pandemi covid-19.

\subsection{Puisi Anak}

Puisi merupakan bentuk karya sastra yang mengungkapkan pikiran dan perasaan penyair secara imajinatif dan disusun dengan mengkonsentrasikan semua kekuatan bahasa dengan pengkonsentrasian struktur fisik dan struktur batinnya (Aryanto, Rony, et al., 2020; Lestari, 2017; Vala \& Marešová, 2014). Puisi dianggap sebagai salah satu karya sastra yang memiliki banyak manfaat bagi para pembaca. Hal tersebut dapat dirasakan dari penggunaan kata-katanya menyentuh emosi pembaca dengan struktur kata yang terikat rima atau ritma (Gunawan, 2019). Puisi juga dianggap sebagai media menyalurkan informasi atau pesan secara padat dan terikat, oleh karena itu kepadatan dan keterikatan bahasa dalam puisi membuat karya sastra ini menjadi jauh lebih indah dan menyentuh. Walaupun banyak yang mengatakan bahwa menulis puisi itu seni yang paling sulit untuk dihayati secara langsung sebagai totalitas. Tetapi, justru di situlah pesan yang ingin disampaikan kepada pembaca untuk menelaah atau memahami indahnya dalam menulis puisi (Gunawan, 2019; Ramadhani, 2020; Yunianta \& Ichsan, 2020). Hal ini berbeda dari puisi anak yang cenderung lebih sederhana dari struktur fisik dan batinnya.

Puisi anak merupakan puisi yang menggambarkan perasaan dan pengalaman anak-anak yang seolah-olah dapat dilihat dan dipahami secara langsung oleh anak. Puisi anak sebagai bagian dari sastra anak apabila isi atau subtansinya (emosi, perasaan, pikiran, saraf sensori, 
dan pengalaman moral) maupun bentuk (kebahasaan dan cara-cara pengekspresian) lebih mudah dipahami oleh anak dan sesuai dengan tingkat perkembanganya (Aryanto \& Widiansyah, 2019). Dari kacamata lain mendefiniskan "Sastra anak tidak harus melulu berkisah tentang anak, tentang dunia anak, tentang berbagai peristiwa yang mesti melibatkan anak.

Puisi anak yang dibuat dalam penelitian ini ditujukan untuk siswa kelas IV dengan karakteristik sesuai dengan Tabel 2.

Tabel 2. Perilaku Berwawasan Lingkungan

\begin{tabular}{|c|c|c|}
\hline No & Aspek & Gambaran \\
\hline \multirow[t]{2}{*}{1} & Bahasa & $\begin{array}{l}\text { a. Ungkapan bahasa lebih sederhana dilihat dari unsur diksi, } \\
\text { struktur, ungkapan, dan kemungkinan pemaknaan }\end{array}$ \\
\hline & & $\begin{array}{l}\text { b. Ungkapan bahasa lebih sederhana dilihat dari unsur diksi, } \\
\text { struktur, ungkapan, dan kemungkinan pemaknaan }\end{array}$ \\
\hline 2 & Pencitraan & $\begin{array}{l}\text { a. pendayaan berbagai ungkapan, citraan serta berbagai } \\
\text { penggambaran masih sebatas jangkauan anak } \\
\text { b. Aspek emosi selalu sejalan dengan cerapan indera }\end{array}$ \\
\hline 3 & Topik/Tema & $\begin{array}{l}\text { Tema yang dibuat sebagian besar menjelaskan tentang } \\
\text { keluarga dan lingkungan alam }\end{array}$ \\
\hline
\end{tabular}

Sumber: (Aryanto, Widiansyah, et al., 2020; Aryanto \& Widiansyah, 2019; Lestari, 2017)

Pengembangan antologi puisi anak dalam penelitian ini meliputi isi dan kemasan yang benar-benar diharapkan merepresentasikan dunia anak sehingga dalam segi isi puisi yang dibuat harus membahas atau mempermasalahkan persoalan yang dapat dipahami anak dan dapat diterima oleh logika mereka. Disamping itu karakteristik karya sastra yang disajikan kepada siswa hendaknya sesuai dengan perkembangannya, baik perkembangan bahasa, kognitif, kepribadian maupun sosial. Dalam segi kemasan antologi puisi anak harus memberikan kesan dan memiliki daya tarik untuk dibaca oleh setiap anak.

\subsection{Internalisasi Nilai-Nilai Ecoprenuership Pada Puisi Anak}

Puisi diyakini sebagai sebagai cara tepat dalam internalisasi nilai-nilai kemanusiaan dan berkaitan dengan hakikat pendidikan dalam upaya memanusiakan manusia (Aryanto \& Widiansyah, 2019) Melalui puisi, anak akan menghayati kejadian-kejadian di lingkungan sekitarnya termasuk menanggapi isu aktual yang terjadi saat ini yakni antisipasi dampak era disrupsi selama pandemi covid-19.

Berikut beberapa aspek dan indikator pengembangan puisi anak berbasis ecopreneurship dapat dilihat melalui tabel 3.

Tabel 3. Aspek dan Indikator Pengembangan Puisi Anak Berbasis Ecopreneurship

\begin{tabular}{lll}
\hline No & \multicolumn{1}{c}{ Aspek } & \multicolumn{1}{c}{ Indikator } \\
\hline $\mathbf{1}$ & $\begin{array}{l}\text { Sensitivity of problem (sensitifitas } \\
\text { terhadap masalah) }\end{array}$ & $\begin{array}{l}\text { Membuat puisi anak dengan topik permasalahan yang telah ditentukan } \\
\text { dan didasarkan pada konsep ecopreneurship }\end{array}$ \\
\hline $\mathbf{2}$ & Fluency (kelancaran) & Puisi anak yang dibuat menggunakan diksi, tipografi, dan pengimajian \\
& & yang disesuaikan dengan karakteristik siswa kelas IV SD pada setiap \\
& & lariknya. \\
\hline
\end{tabular}




\begin{tabular}{cll}
\hline No & \multicolumn{1}{c}{ Aspek } & \multicolumn{1}{c}{ Indikator } \\
\hline $\mathbf{3}$ & Flexibility (keluwesan) & $\begin{array}{l}\text { Pemaknaan kata dalam puisi anak luas dan tidak sempit sehingga } \\
\text { kaya akan pengungkapan perasaan }\end{array}$ \\
\hline $\mathbf{4}$ & Originality (keaslian) & $\begin{array}{l}\text { Sastra yang dibuat menimbulkan kesan yang berbeda dari biasanya } \\
\text { dan menimbulkan daya fantasi yang lebih luas. }\end{array}$ \\
& &
\end{tabular}

Sumber: (Aryanto \& Widiansyah, 2019)

Penelitian yang telah dilakukan menghasilkan 40 puisi yang diharapkan benar-benar merepresentasikan konsep ecoprenuership yang dapat dijadikan referensi bahan ajar di Sekolah Dasar. Nilai-nilai ecopreneurship yang dinternalisasikan pada antologi puisi ini masingmasing diinterpretasikan dalam dua buah puisi untuk setiap nilai, sehingga diharapkan siswa SD dapat menemukan perbedaan nilai pada setiap puisi. Berikut tiga contoh puisi berbasis ecoprenuership yang menginternalisasikan nilai kreativitas, inovasi, tanggung jawab dan peduli terhadap lingkungan.

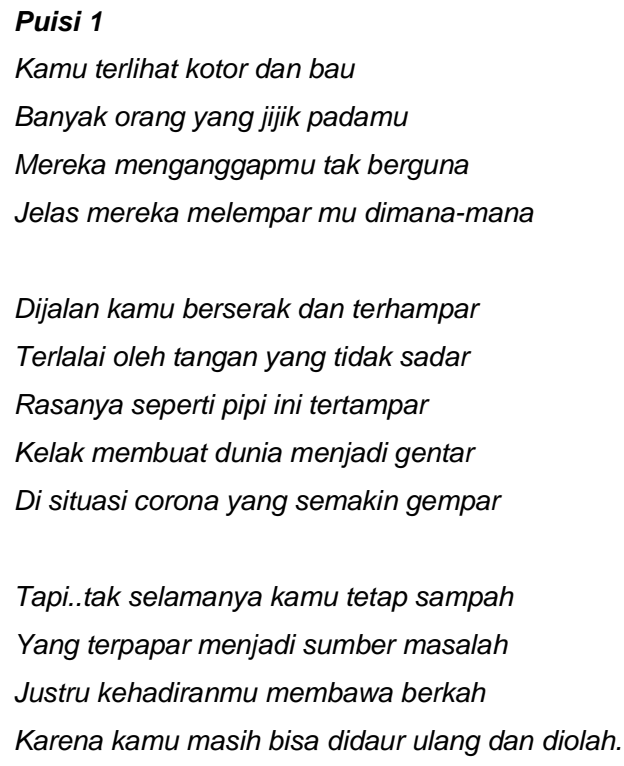

Dalam puisi 1 tampak bahwa nilai yang dominan muncul adalah nilai tanggung jawab seperti pada larik ke empat baris pertama "Jelas mereka melempar mu dimana-mana" yang berarti mengisyaratkan bahwa kita harus bisa bertanggungjawab dalam memperlakukan sampah. Disamping itu nilai tanggung jawab tampak pada larik keenam baris kedua "terlalai oleh tangan yang tidak sadar" yang menggambarkan bahwa sebagian besar manusia membuang sampah tidak pada tempatnya. Namun demikin dalam puisi 1 tidak hanya menginternalisasikan nilai tanggung jawab namun ada nilai kreativitas dan inovasi seperti pada larik ke 12 dan 13 baris ketiga "Justru kehadiranmu membawa berkah" dan "karena kamu masih bisa didaur dan diolah" yang berarti bahwa sampah itu bisa dimanfaarkan dan memiliki nilai jual.

\section{Puisi 2}

Mereka anggap kau tak berguna

Mereka membuangmu dimana-mana

Perusak, itu sebutannya 


\author{
Menghancurkan pesona kota \\ Di tengah musibah corona \\ Tapi tidak untuk ku \\ Kau itu memberi berkah bagiku \\ Mendaurulangmu itu rezeki ku \\ Walau aromamu sangat menusuk ku \\ Kemanakah hati nurani mereka \\ Kau dicampakkan dimana-mana \\ Tanpa disadari,kau punya makna \\ Kau adalah harta \\ Kau membawa wabah \\ Kini, kau adalah sumber berkah
}

Nilai kreativitas dan inovasi mendominasi pada puisi 2, hal ini dapat dilihat dalam kesatuan larik pertama, kedua, ketiga dan keempat yang benar-benar menggambarkan proses pemanfaatan sampah menjadi sumber penghasilan bagi siapa saja yang dapat mengolahnya dengan baik. Hal yang paling tegas mengisyaratkan nilai kreativitas dan inovasi terdapat dalam larik tujuh dan delapan dalam baris kedua "Kau itu memberi berkah bagiku" dan "Mendaurulangmu itu rezeki ku" yang memiliki arti bahwa sampah bisa menjadi berkah atau menguntungkan bagi siapapun yang memiliki kreativitas dan inovasi.

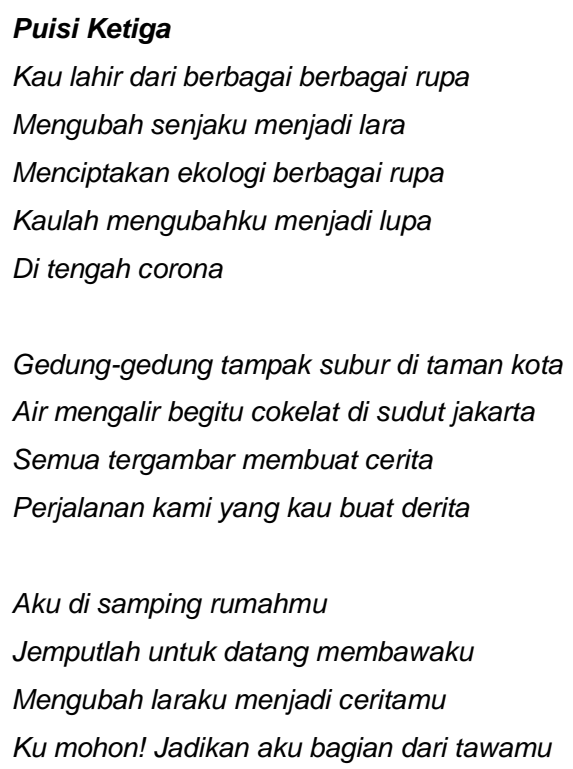

Nilai kepedulian lingkungan sangat tampak pada puisi ketiga ini, makna konotatif sangat melekat di setiap larik di baris pertama, kedua, dan ketiga. Walaupun pemaknaan disusun secara tersirat namun dominasi nilai kepedulian lingkungan dapat di lihat melalui larik keenam dan ketujuh di baris kedua "gedung-gedung tampak subur di taman kota" dan "air mengalir begitu cokelat di sudut Jakarta". Kedua larik tersebut merupakan sindiran keras terhadap 
manusia yang mempersempit lahan hijau dengan pembangunan gedung-gedung yang menjulang dan terkadang perilaku pemanfaatan lingkungan alam dilakukan secara tidak bijak sehingga mengakibatkan polusi yang membuat perairan sungai di Jakarta tampak keruh dan tidak sehat.

Ketiga puisi tersebut merupakan bagian dari antologi puisi yang sedang dikembangkan dan diharapkan benar-benar merepresentasikan kebutuhan dunia pendidikan di SD dalam prespektif sastra sebagai bagian penting dalam mengembalikan hakikat pendidikan yang dapat memanusiakan manusia agar lebih manusiawi. Apalagi kini dunia sedang dihadapkan era disrupsi dan pandemi covid 19 yang menuntut setiap bidang untuk mampu berinovasi dan mencari upaya solutif secara preventif maupun kuratif.

\section{Kesimpulan}

Pengembangan antologi berbasis ecoprenuership merupakan salah satu upaya antisipatif dalam menghadapi era disruptif selama pandemi covid-19. Hasil penelitian ini menggambarkan bahwa terdapat beberapa toeri yang relevan dalam mengembangkan antologi yang diharapkan representatif dengan karakteristik dan kebutuhan siswa Sekolah Dasar. Beberapa teori yang relevan diantaranya: konsep ecopreneurship, nilai-nilai ecopreneurship, karakteristik puisi anak, dan internalisasi nilai-nilai ecopreneurship pada puisi anak. Tahap pengembangan antologi sudah mencapai 50\% dengan jumlah puisi mencapai 40 karya yang diharapkan benar-benar merepresentasikan konsep ecopreneurship di Sekolah Dasar.

\section{Ucapan Terima Kasih}

Terimakasih kepada seluruh pihak yang telah membantu selama proses penyusunan artikel ini terutama pihak Kemenristekdikti yang telah memberikan dukungan material melalui Pendanaan HIBAH PDP Tahun 2020 dan LPPMP Universitas Bhayangkara Jakarta Raya, SDN Harapan Baru II dan SD Teluk Pucung I serta pihak-pihak lainnya yang telah memberikan dukungan materil maupun non materil.

\section{Daftar Pustaka}

Aryanto, S. (2016). The Implementation Of Edupreneurship Based On Local Wisdom In Primary School As An Effort To Prepare Indonesian Golden Era. Education In The 21st Century :Responding To Current Issues, 787-793.

Aryanto, S., Markum, M., Pratiwi, V., \& Husadha, C. (2019). Ecobrick Sebagai Sarana Pengembangan Diri Berbasis Ecopreneurship Di Sekolah Dasar. Dwija Cendekia: Jurnal Riset Pedagogik, 3(1), 93. Https://Doi.Org/10.20961/Jdc.V3i1.34076

Aryanto, S., Rony, Z. T., Diba, F., \& Putri, C. (2020). Implementasi Metode Scaffolding Dalam Membuat Puisi Berbasis Ecoliteracy Pada Anak-Anak Penghuni Lapas Salemba. 3(2), 171-180.

Aryanto, S., \& Syaodih, E. (2017). Development Of Ecopreneurship In Primary School. IJAEDU- 
International E-Journal Of Advances In Education, III(9), 597-602. Https://Doi.Org/10.18768/ljaedu.370428

Aryanto, S., \& Widiansyah, A. (2019). Indonesian Journal Of Primary Education Kreativitas Dalam Pembuatan Sastra Anak Berbasis Ecopreneurship. 3(2), 83-90.

Aryanto, S., Widiansyah, A., \& Markum, M. (2020). Peningkatan Kemampuan Berprikir Kreatif Dalam Pembuatan Sastra Anak Berbasis Ecopreneurship Melalui Implementasi Design Thinking. Educational Journal Of Bhayangkara, 1(1), 37-44. Https://Doi.Org/10.31599/Edukarya.V1i1.107

Bikdeli, B., Madhavan, M. V., Jimenez, D., Chuich, T., Dreyfus, I., Driggin, E., Nigoghossian, C. Der, Ageno, W., Madjid, M., Guo, Y., Tang, L. V., Hu, Y., Giri, J., Cushman, M., Quéré, I., Dimakakos, E. P., Gibson, C. M., Lippi, G., Favaloro, E. J., ... Lip, G. Y. H. (2020). COVID19 And Thrombotic Or Thromboembolic Disease: Implications For Prevention, Antithrombotic Therapy, And Follow-Up: JACC State-Of-The-Art Review. Journal Of The American College Of Cardiology, 75(23), 2950-2973. Https://Doi.Org/10.1016/J.Jacc.2020.04.031

Dixon, S. E. A., \& Clifford, A. (2007). Ecopreneurship - A New Approach To Managing The Triple Bottom Line. Journal Of Organizational Change Management, 20(3), 326-345. Https://Doi.Org/10.1108/09534810710740164

Ekayanti, N. W., Puspawati, D. A., Putu, S., \& Surata, K. (2011). Upaya Peningkatan Keterampilan Sosial Dalam Pendidikan Biologi Semester lii Tahun. 1(1), 14-21.

Fan, L., Jiang, S., Yang, X., Wang, Z., \& Yang, C. (2020). COVID-19 Drug Treatment In China. Current Pharmacology Reports, 1-9. Https://Doi.Org/10.1007/S40495-020-00218-5

Gunawan, G. (2019). Hubungan Penguasaan Kosakata Dengan Kemampuan Menulis Puisi Pada Siswa Kelas X lis Sma Negeri 1 Cigudeg Bogor. 02(April), 36-43.

Handayanto, R. T., \& Herlawati, H. (2020). Efektifitas Pembatasan Sosial Berskala Besar (PSBB) Di Kota Bekasi Dalam Mengatasi COVID-19 Dengan Model Susceptible-InfectedRecovered (SIR). Jurnal Kajian Ilmiah, 20(2), 119-124. Https://Doi.Org/10.31599/Jki.V20i2.119

Herlawati, H. (2020). COVID-19 Spread Pattern Using Support Vector Regression. PIKSEL : Penelitian IImu Komputer Sistem Embedded And Logic, 8(1), 67-74. Https://Doi.Org/10.33558/Piksel.V8i1.2024

Kiky, A. (2020). Manajemen Resiko Terhadap Black Swan Event Maret 2020 Di Indonesia. Studi Kasus Efek Covid-19 Terhadap Pasar Modal Indonesia. Jurnal Bina Manajemen, 8(2), 90-105.

Lestari, A. (2017). Keefektifan Media Audio Visual Sebagai Kreativitas Guru Sekolah Dasar Dalam Menumbuhkan Keterampilan Menulis Puisi Siswa. Scholaria: Jurnal Pendidikan Dan Kebudayaan, 7(3), 214. Https://Doi.Org/10.24246/J.Scholaria.2017.V7.I3.P214-225 Nacu, C. M., \& Avasilcăi, S. (2014). Technological Ecopreneurship: Conceptual Approaches. Procedia - Social And Behavioral Sciences, 124, 229-235. 
Https://Doi.Org/10.1016/J.Sbspro.2014.02.481

Nadiroh, \& Siregar, S. M. (2019). Analisis Kemampuan Memecahkan Permasalahan Lingkungan Dan Ekoliterasi Siswa. Jurnal Parameter, 31(2), 96-103.

Ramadhani, S. (2020). Model Pembelajaran Sinektik Dan Penguasaan Kosakata Terhadap Keterampilanmenulis Puisi Siswakelas $V$ Sd Pangeran Antasari Medan Tahunpembelajaran 2020. Juranal Pendidikan, 7(1), 12-22.

Rony, Z., \& Aryanto, S. (2020). Coaching Competency As A Solution For Indonesian Headmaster Of Elementary School In Disruption Era. Https://Doi.Org/10.4108/Eai.13-22019.2286504

Sanchis-Gomar, F., Lavie, C. J., Mehra, M. R., Henry, B. M., \& Lippi, G. (2020). Obesity And Outcomes In COVID-19: When An Epidemic And Pandemic Collide. Mayo Clinic Proceedings. Https://Doi.Org/10.1016/J.Mayocp.2020.05.006

Schaltegger, S. (2014). A Framework For Ecopreneurship. Greener Management International, 2002(38), 45-58. Https://Doi.Org/10.9774/Gleaf.3062.2002.Su.00006

Schaper, M. (2002). The Essence Of Ecopreneurship. Greener Management International, 38, 26-30. Https://Doi.Org/10.9774/GLEAF.3062.2002.Su.00004

Singh, R., \& Subedi, M. (2020). COVID-19 And Stigma: Social Discrimination Towards Frontline Healthcare Providers And COVID-19 Recovered Patients In Nepal. Asian Journal Of Psychiatry, 53(June), 102222. Https://Doi.Org/10.1016/J.Ajp.2020.102222

Uslu, Y. D., Hancıoğlu, Y., \& Demir, E. (2015). Applicability To Green Entrepreneurship In Turkey: A Situation Analysis. Procedia - Social And Behavioral Sciences, 195, 1238-1245. Https://Doi.Org/10.1016/J.Sbspro.2015.06.266

Vala, J., \& Marešová, H. (2014). The Comparison Of Reception Of Selected Poems By Students From Varied Schools. Procedia - Social And Behavioral Sciences, 112(Iceepsy 2013), 284-289. Https://Doi.Org/10.1016/J.Sbspro.2014.01.1166

Yunianta, R. D., \& Ichsan, A. S. (2020). Peningkatan Kemampuan Menulis Puisi Melalui Media Kisah Kepahlawanan Tokoh Wayang Pada Siswa Kelas V SD 2 Panjangrejo Pundong Bantul. 3(1), 103-114. 